\title{
（11） ボーリング繰粉の粒度とメチレンブルー吸着特性について
}

\section{1.はじめに}

先進ボーリングなどの綝粉について、従来からガス突 出の危険性の予知及び予防対策のため多くの調查研究が 行われてきた。しかしながら、繰粉とガス突出との関連 性を胃いだして十分活用するまでには至っていない。 絽粉には、炭層内部の有用な情報が多く含まれていると 思われ、ガス突出対策にとつて有効な情報が得られるな なら、この情報をもとに現場でガス突出に関連する予知 が可能と思われる。

綝粉からの予知法では、石浜ら11 は石炭のメチレンブ ルー吸着による溶液の脱色度合いを比較して、石炭のメ タンガス包藏能力の大小を推定してガス突出の危険性を 尒知するメチレンブルー法を提案している。

このメチレンブルー（以下、MBと略称する）法は現 場で簡単に行える利点を持っているが、詳細な検討は十 分おこなおれていない。

筆者は、MB法の有效性と現場適用を探るため、空知 炭鉱並びに赤平炭鉱の協力を得て、石炭のM B 吸着に影 響を及ぼす粒度及び炭質、ガス突出子知の判定の基準と なりうるMB吸着量とメタンガス吸着能との関係など数 項目について検討を行っている。

本報告では、繰粉の粒度分布及びMB 法の概要と石炭 のMB吸着について述へる。

\section{2 . 供試試料}

試料は、空知炭鉱の先進ボーリング（石油警井機社製 $\mathrm{P}-4$ 型機、平型ビット、さく孔径 $65 \mathrm{~mm}$ 、集塵はベン チュリー方式）及び赤平炭鉱のゆるめ大口径ボーリング

\section{資源環境技術総合研究所(北海道) 佐 藤 英 -}

$250 \mathrm{~mm}$ ) で、深け側の石炭繰粉を対象とした。

試料採取は $5 \mathrm{~m}$ 間隔で行い、その量は250〜 $1200 \mathrm{~g}$ の 範囲であつた。

対象炭層は、空知炭鉱では- $430 \mathrm{~mL}$ L登川の 2 番層、 3 番下層及び 5 番層である。赤平炭鉱は- $690 \mathrm{~mL}$ の夕張 6 番層、 $-770 \mathrm{~mL}$ の美咀 9 番層及び- $620 \mathrm{~m} \mathrm{~L}$ の若鍋 7 番 層などである。

表 1 に 炭鉱のボーリング諸条件を示した。

3 . 粒度分布

3-1湘定方法

繰粉の粒度分布の測定は、フルイ分け法で、後述する MB法を考慮して細粒子側を対象とした。その対象粒子 は500 $\mu \mathrm{m}$ 以下とした。

盖子範囲は75 $\mu \mathrm{m}$ 以下、 $75 \sim 150 \mu \mathrm{m} 、 150 \sim 250 \mu \mathrm{m}$ $250 \sim 500 \mu \mathrm{m}$ 及び $500 \mu \mathrm{m}$ 以上の 5 区分である。

フルイ分けは、J I S 規格のフルイを用い、ロータッ プシェーカーに50 分間かけて各粒度の重量を剆定した。

\section{$3-2$ 測定結果}

繰粉の粒度とその量は、さく孔速度、ビットの形状及 び炭層状態などによって左右される。特にさく孔時の応 力集中によるボーリング孔周辺の石炭の破碎粒子は他の 粒子と異なり、ガス突出と関連があるものと推湘する。

いま、空知と赤平の両試料の測定結果を図 1 及び図 2 に示した。

図は、一さく孔あたりの重量積算フルイ下の平均値と

表 1 各炭鉣のボーリング墸条件

\begin{tabular}{|c|c|c|c|c|c|c|c|c|c|c|c|c|}
\hline \multirow{3}{*}{$\begin{array}{lll}\text { 炭 } & \text { 鉱 } & \text { 名 } \\
\text { 岸 } & \text { 層 } & \text { 名 } \\
\text { 試 } & \text { 料 } & \text { 名 }\end{array}$} & \multicolumn{6}{|c|}{ 鉱 } & \multicolumn{6}{|c|}{ 赤平炭鉱 } \\
\hline & \multirow{2}{*}{$\frac{\text { 登川2番層 }}{\mathrm{S} 2}$} & \multicolumn{2}{|c|}{ 登川 3 番下層 } & \multicolumn{3}{|c|}{ 登川 5 番 層 } & \multicolumn{2}{|c|}{ 夕張 6 番 層 } & \multicolumn{2}{|c|}{ 美咀 9 番層 } & \multicolumn{2}{|c|}{ 若銅 7 番 層 } \\
\hline & & S 3-1 & S $3-2$ & S 5 $5-1$ & S $5-2$ & $S 5-3$ & A $1-1$ & A $1-2$ & A $3-2$ & A $3-3$ & A $4-1$ & A $4-2$ \\
\hline ボーリング來名 & A & B & B & C & C & $\mathrm{D}$ & A & A & B & B & C & C \\
\hline 岸 丈 $\quad(m)$ & 2.2 & 2.2 & 2.2 & 2.7 & 2.7 & 3.2 & 5.0 & 5.0 & 4.0 & 4.0 & 4.5 & 4.5 \\
\hline 峞層傾斜 $\left(0^{\circ}\right)$ & 45 & 80 & 80 & 56 & 56 & 43 & $10 \sim 12$ & $10 \sim 12$ & $24 \sim 26$ & $24 \sim 26$ & $5 \sim 6$ & $5 \sim 6$ \\
\hline 掘僬方向 $\left(^{\circ}\right)$ & 右 14 & 左 8 & 左 8 & 右 14 & 右 14 & 左40 & 中心 & 右15 & 左 15 & 左 15 & 中心 & 中心 \\
\hline 掘進傾斜 $\left(^{\circ}\right)$ & +9 & -4 & -4 & +12 & +12 & J & \pm 0 & +3 & +13 & +13 & +13 & +13 \\
\hline 全さく孔長 (m) & 50 & 40 & 60 & 40 & 37 & 0 & 20 & 20 & 11 & 11.3 & 6 & 20 \\
\hline さく孔速度(分/四) & 1.6 & 1.0 & 1.0 & 0.7 & 0.6 & 1.6 & 13 & 9 & .12 & 20 & 7 & 7 \\
\hline 繰粉量 $(\ell / m)$ & 9.2 & 6.4 & 7.1 & 4.0 & 3.3 & 6.9 & 299 & 235 & 205 & 152 & 110 & 291 \\
\hline 妿 ス涌出 & なし & なし & なし & 一部有り & なし & なし & なし & なし & なし & なし & なし & 一部有り \\
\hline
\end{tabular}


平均粒子径（粒子間平均値）との関係を表している。

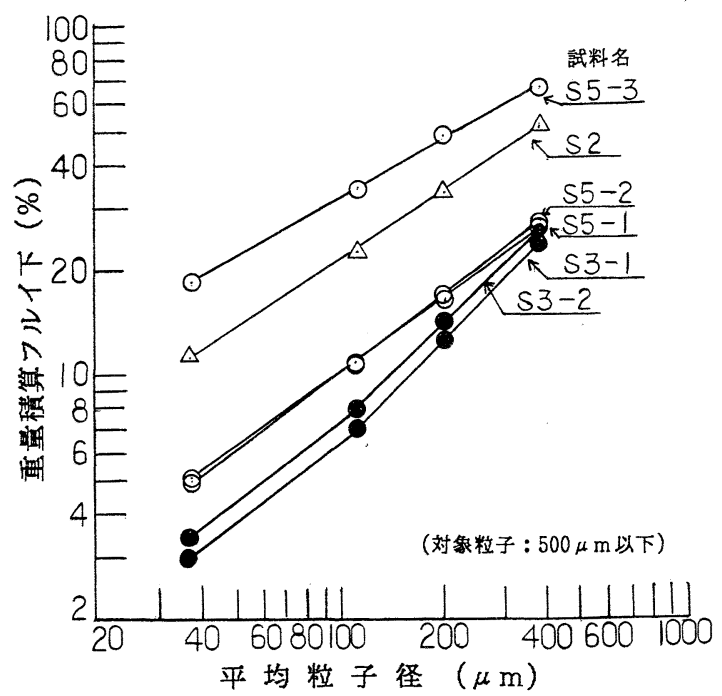

図 1 空知炭鉱の絽粉の積算粒度分布

図 1 から、空知試料の3 炭層 (S 2、S 3、S 5 の各 炭層一表 1 参照）の粒度分布をみると、その分布率は炭 層ごとに異なるが、各粒子の分布率の範囲は広い。分布 率と粒子径との関係は直線性を示して分布関数で表すこ とがでさる。

またボーリング座から同じ角度と傾斜で 2 本さく孔し た時の粒度分布を、試料S 3 及びS 5 の 1 と 2 の両者で みると、炭層ごとにほぼ同じ傾问の值を示している。 しかし、同じ炭層でも試料 S 5-3のようにボーリング 箇所が変わると、粒子の分布率に地域差がみられるが、 その理由については判然としない。

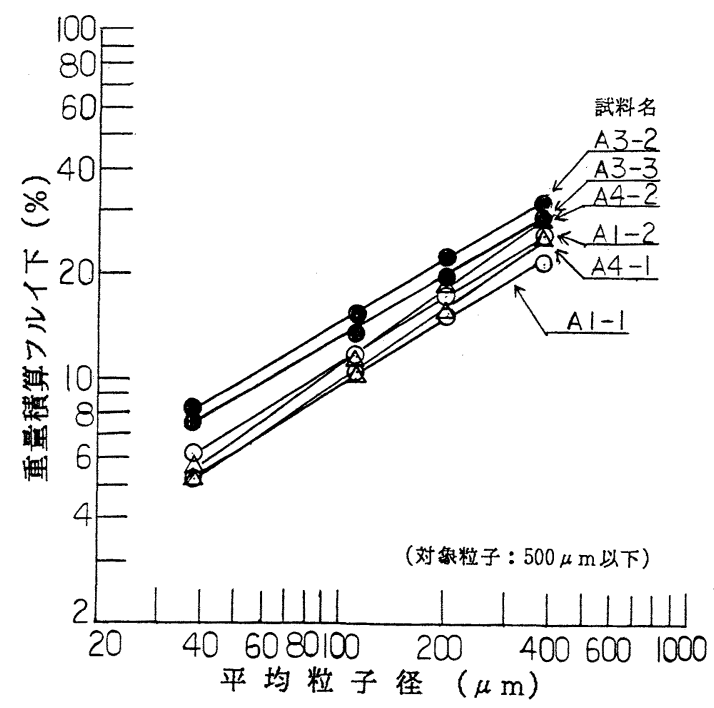

図 2 赤平炭鉱の繰粉の皘算粒度分布

次に、図 2 から、赤平試料の 3 炭層 (A 1、A 3、 A 4 -表 1 参照）の粒度分布をみると、その分布率は各 炭層で多少異なる程度で、75 $\mu$ m以下粒子は 5 8\% の範囲に対して、500 $\mu \mathrm{m}$ 以上の粒子は約70\%以上とな っている。分布率と粒子径との関係では空知試料同様に、
直線性を示して分布関数を表すことができる。

また各炭層のボーリング座で 2 本さく孔した場合の粒 度分布では、空知試料と同様な結果を示した。

以上、空知及び赤平の繰粉の粒度分布測定結果は、 $500 \mu \mathrm{m}$ 以下の粒子では粒子径と分布率との関係を分布 関数で表すことができ、その関数のパラメーターは後述 するMB吸着の解析に活用できる可能性があり、もう少 しデータを蓄積して検討する必要がある。

4.メチレンブルー吸着

4-1測定方法

石炭のM B 吸着は、J I S K-1474 に規定されている 活性炭の性能試験方法に準抛し、北開試法 ${ }^{2)} 775 \mu \mathrm{m}$ 以 下の粒子を主対象にして行つた。

湘定方法は、 $45 \mathrm{~m} \mathrm{~g} / \ell$ の M 溶液 $50 \mathrm{ml}$ と、精积した 試料 $1 \mathrm{~g}$ を共栓付三角フラスコに入れ、45分間水平振と う (300SPM) 後、遠心分離器 (3500rpm) にが、その 上澄み液を分光光度計を用いて波長 $665 \mathrm{~nm}$ 的けける吸 光度を測定し、残留MB濃度から検量線を用いてMB吸 着量を求める。

$\mathrm{MB}$ 溶液温度は、18.5 23.0 $0^{\circ} \mathrm{C}$ 範囲で行つた。また 試料の前処理は、 $80^{\circ} \mathrm{C} の-0.93 \mathrm{MPa}$ で 2 時間真空乾燥を 行つた。なおMB溶液にはリン酸塩緩衝液を使用した。

\section{4-2测定結果}

石炭のM B 吸着量は、試料の粒度によつて左右され、 細粒子ほど吸着量は大きくなると云われている。

いま、図 3 に粒度によるMB吸着量の変化を示した。

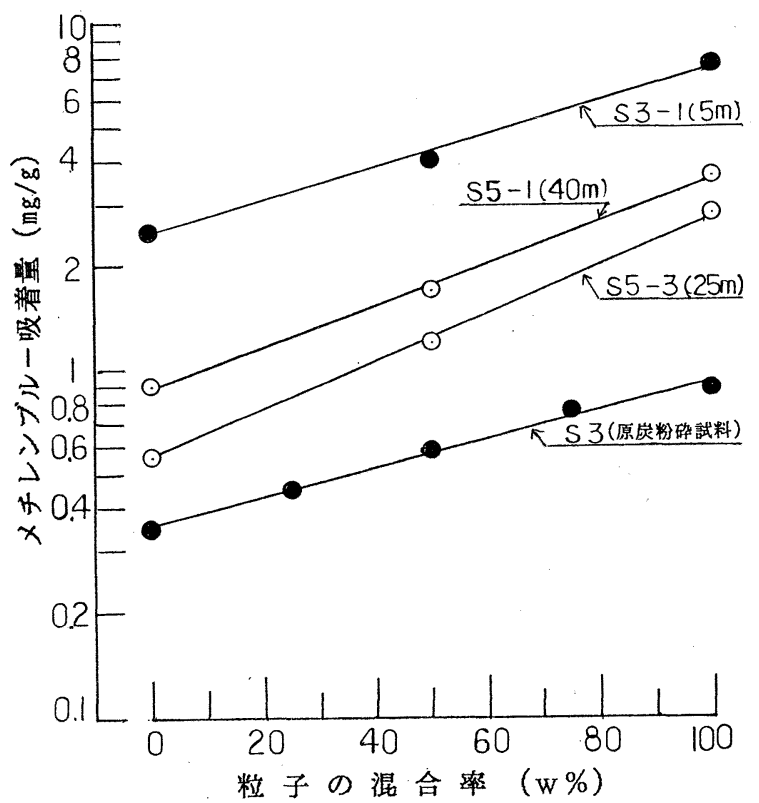

図 $375 \mu \mathrm{m}$ 以下の粒子と $75 \sim 150 \mu \mathrm{m}$ の粒子との 混合割合によるメチレンブルー吸着量の変化 (75 150 $\mu \mathrm{m}$ の粒子を $0 、 75 \mu \mathrm{m}$ 以下の粒子を 100 とする) 
図には $75 \mu \mathrm{m}$ 以下の粒子と $75 \sim 150 \mu \mathrm{m}$ の粒子の混合割 合によるMB吸着量の変化を、空知試料のS 3 と S 5 に ついて記した。混合率 $100 \%$ \% $75 \mu \mathrm{m}$ 以下の粒子とした。

なお、試料のS 3 は採取試料と原炭の粉砕試料である。 また試料のS 5 は採取試料で、（）内は採取距離である。

この図から、採取試料及び原炭粉砕試料ともに $75 \mu \mathrm{m}$ 以下の粒子の混合割合が多くなるほど吸着量も多くなり、 75〜150 $\mu \mathrm{m}$ の粒子と比べて 3〜 4倍の高い値を示して いる。このように、細粒子が吸着量に影響を及ぼすとと もに、MB吸着量と粒子の混合率とに相関性がみられる。

また、S 3 の採取試料と原炭粉砕試料とお比べるてみ ると、採取試料の方が吸着量が多く、繰粉と原炭との相 違を示していると思われるが、その理由を検討中である。

次に、空知及び赤平の両試料の $75 \mu \mathrm{m}$ 以下の粒子につ いて、MB吸着量を测定し、試料採取距離との関係を図 4 と図5に示した。

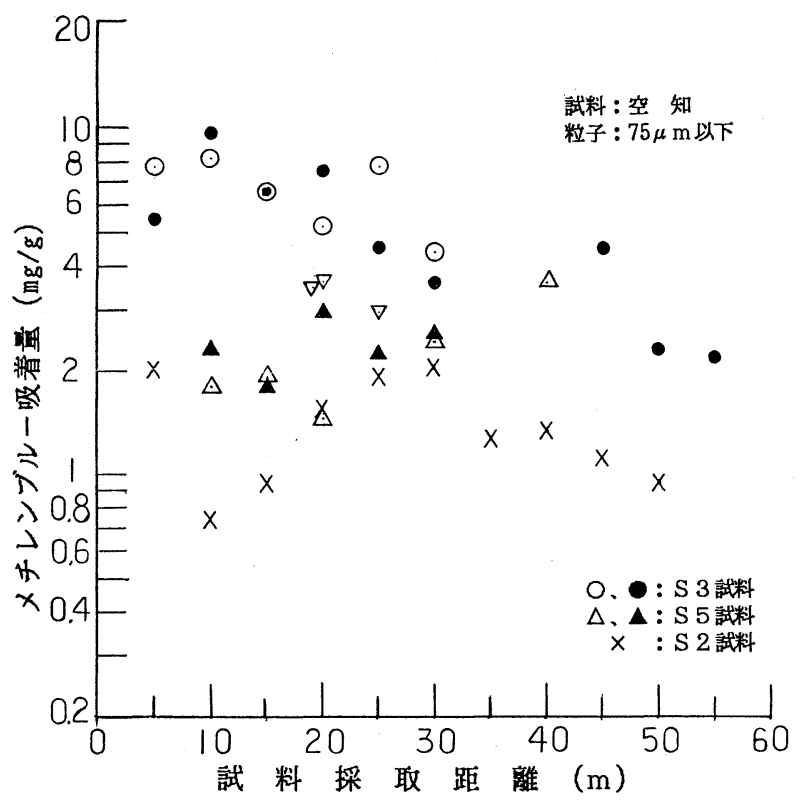

図4 試料採取距離とメチレンブルー吸着量との関係

図4の空知試料では、試料 S 3 のMB吸着量は試料の 採取地点が奥部になるほど吸着量が下がるが、一定した 吸着傾向がみられるのに対し、他の試料では吸着傾向は 余りみられない。

図5の赤平試料では、試料によつては採取地点に関係 なく、一定した吸着量がみられるが、空知試料同様に、 繰粉の吸着特性を把握するまでには至つていない。

なお、繰粉のMB吸着において、石炭試料に岩石が混 入すると吸着量が多くなる傾向にある。岩石の吸着量は 石炭より多く、岩石の種類にもよるが 10 数 $\mathrm{m} g / \mathrm{g}$ 以 上の值が計測されている。

以上、石炭の MB吸着について簡単にのべてきたが、 吸着特性を把握するにはデータの蓄積が必要である。

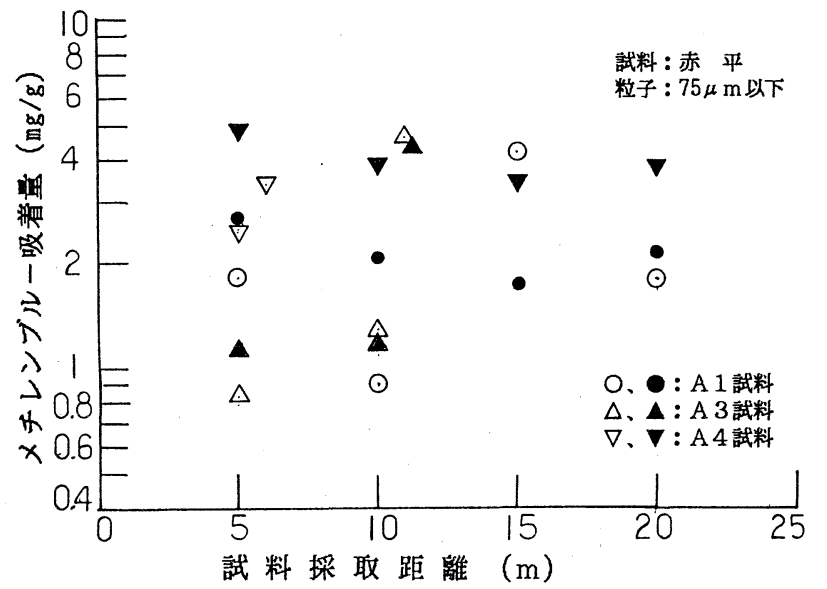

困5 試料採取距離とメチレンブルー吸着量との関係 また、石炭のMB吸着では、石炭自身のM B 吸着量は活

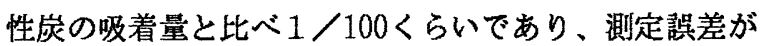
値に大きく影響することがわかった。

5.おおりに

坑内の見場で可能な、繰粉からのガス突出の危険性の 予知法として、石炭のメチレンブルー法について検討を 行つているが、繰粉の粒子500 $\mu \mathrm{m}$ 以下の粒度分布を明 らかにするとともに、石炭に対するMB吸着の方法を確 立することができた。

今後も、多くの綝粉の粒度分布及びMB吸着量などの 重要項目を測定し、ガス突出の予知の手がかりをつかみ たい所存です。

\section{謝 辞}

本研究の実施にあたり、ご指導を賜つた元東北大学教 授 石浜 涉氏並びに元北海道工業技術研究所石橋一二 氏、更に試料を提供して下さいました空知炭鉱株式会社 並びに赤平炭鉱株式会社の関係各位に媣甚なる謝意を表 します。

参考文献

1）石浜 他 : 炭鉱の生産性と安全性の向上並びに作業 環境の改善に関する総合的連絡研究、昭和 57 年度 文部省科研費報告書、PP63-74 昭和 58 年 3 月

2）伊藤 他：公害特別研究成果集、49-II 昭和 63 年 8 月 